\title{
Australian Journal of

\section{Physico-chemical properties and sensory profile of Coffea canephora genotypes in high-altitudes}

\author{
Carlos Alexandre Pinheiro ${ }^{1}$, Lucas Louzada Pereira ${ }^{2}$, Deusélio Bassini Fioresi ${ }^{2}$, Daniela da Silva Oliveira ${ }^{3}$, \\ Vanessa Moreira Osório ${ }^{1}$, Josimar Aleixo da Silva ${ }^{4}$, Ulisses Alves Pereira ${ }^{5}$, Maria Amélia Gava Ferrão ${ }^{6}$, \\ Elaine Manelli Riva-Souza ${ }^{7}$, Aymbiré Francisco Almeida da Fonseca ${ }^{6}$, Patrícia Fontes Pinheiro ${ }^{{ }^{*}}$
}

${ }^{1}$ Programa de Pós-graduação em Agroquímica, Departamento de Química e Física, Centro de Ciências Exatas, Naturais e da Saúde, Universidade Federal do Espírito Santo, Alto Universitário, sn, Guararema, CEP: 29500-000, Alegre, Espírito Santo, Brasil

${ }^{2}$ Instituto Federal do Espírito Santo. Departamento de Ciência de Alimentos. Avenida Elizabeth Minete Perim, S/N. Bairro São Rafael, CEP: 29375-000, Venda Nova do Imigrante, Espírito Santo, Brasil ${ }^{3}$ Departamento de Farmácia e Nutrição, Centro de Ciências Exatas, Naturais e da Saúde, Universidade Federal do Espírito Santo, Alto Universitário, sn, Guararema, CEP: 29500-000, Alegre, Espírito Santo, Brasil ${ }^{4}$ Departamentode Biologia, Centro de Ciências Exatas, Naturais e da Saúde, Universidade Federal do Espírito Santo, Alto Universitário, sn, Guararema, CEP: 29500-000, Alegre, Espírito Santo, Brasil ${ }^{5}$ Instituto de Ciências Agrárias (ICA), Universidade Federal de Minas Gerais, Campus Regional de Montes Claros, Avenida Universitária, 1.000, Bairro Universitário, CEP: 39404-547, Montes Claros, Minas Gerais, Brasil ${ }^{6}$ EmbrapaCafé/Incaper Empresa Brasileira de Pesquisa Agropecuária. Rua Afonso Sarlo, 160 - Bairro Bento Ferreira, CEP: 29052-010, Vitória, Espírito Santo, Brasil

${ }^{7}$ Instituto Capixaba de Pesquisa. Assistência Técnica e Extensão Rural (Incaper). Rua Afonso Sarlo, 160 - Bairro Bento Ferreira, CEP: 29052-010, Vitória, Espírito Santo, Brasil

\section{*Corresponding author: patriciafontespinheiro@yahoo.com.br}

Abstract

In Brazil, Coffea canephora coffee is generally cultivated in hot climate regions and at altitudes below $400-450 \mathrm{~m}$. There is little information on $C$. canephora cultivation at higher altitudes. Thus, the objective of this work was to determine the physicochemical properties and to perform the sensorial analysis of 21 different Coffea canephora coffee genotypes, grown at $720 \mathrm{~m}$ altitude in the state of Espírito Santo, Brazil. The field experiment was implemented in 2011 at the Incaper, Experimental Farm of Venda Nova using randomized block design, with four replications, eight plants per plot and spacing of $3.0 \times 1.0 \mathrm{~m}$. Thirteen clones of the clonal cultivar Vitória Incaper 8142 (V1 to V13) and eight clones of the clonal cultivar Robustão Capixaba Emcapa 8141 (R1, R2, R3, R6, R7, R8, R9 and R10) were studied. Grain samples were obtained from the third harvest in 2016. The harvest was performed when more than $80 \%$ of the fruits were ripe (August) and the freshly harvested coffee was processed using the conventional terrace drying method (natural processing). After the coffee was dried and processed, the four replicates were of each treatment were combined for the physicochemical analyses. The physicochemical analyses were performed (total titratable acidity, $\mathrm{pH}$ at $25^{\circ} \mathrm{C}$ and $96^{\circ} \mathrm{C}$ ), reducing, non-reducing and total sugars were determined, chlorogenic acid (5-CQA), trigonelline and caffeine levels were determined by HPLC using the external standard method. Chlorogenic acid contents were found in the range of 2.60 to $3.65 \%$. Caffeine levels ranged from 2.06 to $2.89 \%$. There was no statistical difference in the final scores of the sensory analysis of the $C$. canephora coffees and the average value was 77.44 points, the same score for high-quality/premium coffee. Cultivation of $C$. canephora at high altitudes can be promising to obtain higher quality coffees from C. canephora species.

Keywords: Conilon coffee, Robusta coffee, chemical composition, genotypes, altitude, quality.

Introduction

Brazil is the largest producer and the second largest consumer of coffee in the world, with an average consumption of 20 million bags per year. The species of coffee of higher economic importance in Brazil are Coffea arabica and Coffea canephora, which account for about $74 \%$ and $26 \%$, respectively, of national production (Conab, 2017). The state of Espírito Santo (ES) is the leader in the production of $C$. canephora in Brazil. The cultivation of this coffee on capixaba lands (lands in the state of Espírito Santo) began in the 1970s, but it was from 1985 onwards that the research and rural extension work in the state were 
intensified (Ferrão et al., 2017). In this context, many genetic materials with superior agronomic characteristics were selected and developed by INCAPER's conilon coffee breeding program, resulting in the launch and recommendation of 10 cultivars for Espírito Santo, nine clonal cultivars and one obtained by seed propagation. These cultivars constitute the basis of the coffee state park: 'Emcapa 8111', 'Emcapa 8121' and 'Emcapa 8131' (Bragança et al., 2001); 'Emcapa 8142 - Robustão Capixaba' (Ferrão et al., 1999); 'Emcaper 8151 - Tropical Robusta' (Ferrão et al., 2000); 'Vitoria Incaper 8142' (Fonseca et al., 2004); 'Diamante ES8112', 'Jequitibá ES8122', 'Centenary ES8132' (Ferrão et al., 2013) and 'Marilândia ES8143 (Ferreira et al., 2017). Despite the great evolution in coffee production, quality has been a factor of growing concern for researchers and for the coffee agribusiness (Lima Filho et al., 2013).

Factors that influence coffee quality have been researched and are quite complex. The ones that stand our among them are planting site; soil type; coffee species; genetic aspects (Ramalho et al., 2016); climate (Dandendo et al., 2014; Martins et al., 2015); harvesting (Fagan et al., 2011); drying; storage (Coradi, 2008); dry and wet processing (Giomo, 2012); roasting and milling (Schmidt et al., 2008). Among the environmental factors, the planting site may have a particular influence on the production of higher quality coffees, due to differences in temperature and rainfall regime. According to Laviola et al. (2007), at higher altitudes the coffee tree may have greater accumulation of photoassimilates in leaves and fruits, due to the slower maturation influenced by lower temperatures. Following this approach, Fritzsons et al. (2008) reported that at each 180meter altitude increase, the temperature decreases around 1 degree Celsius and there is higher average rainfall. $C$. canephora in Brazil is generally cultivated at altitudes below 400-450 m, in hot climate regions (Matiello, 1991; Dadalto and Barbosa, 1997). Worldwide, coffee quality is determined by a qualitative method, the cup test (sensorial analysis), carried out by trained professionals, where the aroma, acidity, bitterness, sweetness, astringency and body of the beverage are evaluated. The aspects evaluated in the sensorial analysis are directly related to the chemical constituents present in the coffee beans (Figueiredo et al., 2018). The physicochemical parameters of the coffee can be used to determine desirable coffee quality factors such as: $\mathrm{pH}$ and total titratable acidity (Borém et al., 2008), as well as the constituents that influence coffee flavor, such as reducing, non-reducing and total sugars, as well as the levels of chlorogenic acids, trigonelline and caffeine (Farah et al., 2006). The objective of this work was to quantitatively determine the physicochemical characteristics and to perform the sensory analysis of different genotypes of $C$. canephora, grown at $720 \mathrm{~m}$ altitude, in order to investigate the potential quality of this species.

\section{Results and Discussion}

\section{Coffee acidity (C. canephora)}

Table 1 shows the values of total titratable acidity (TTA), $\mathrm{pH}$ at 25 and $96^{\circ} \mathrm{C}$ for $C$. canephora coffee samples. There was no significant difference for the TTA values of the $21 \mathrm{C}$. canephora samples and the mean value was $178.09(\mathrm{~mL}$ of
$\left.\mathrm{NaOHO} .1 \mathrm{~mol} \mathrm{~L}^{-1} / 100 \mathrm{~g}\right)$. Pinheiro et al. (2012) found TTA values above 200 ( $\mathrm{mL}$ of $\mathrm{NaOH} 0.1 \mathrm{~mol} \mathrm{~L}^{-1} / 100 \mathrm{~g}$ ) for raw $C$. canephora coffee beans dried by fire or sun-dried on concrete or brick patios. Values below $142(\mathrm{~mL} \mathrm{NaOH} \mathrm{0,1}$ $\mathrm{mol} \mathrm{L}^{-1} / 100 \mathrm{~g}$ ) were obtained for higher quality coffees dried in a greenhouse, indicating that the higher the TTA value, the higher the acidity, the lower the coffee quality. Partelli et al. (2014) found total titratable acidity equal to 213 ( $\mathrm{mL}$ of $\mathrm{NaOH} 0.1 \mathrm{~mol} \mathrm{~L}^{-1} / 100 \mathrm{~g}$ ) for a sample of conilon coffee with $13 \%$ humidity and 75.50 points of sensory analysis.

The $\mathrm{pH}$ values at $25^{\circ} \mathrm{C}$ were very close for all samples analyzed (mean value of 5.99), and $\mathrm{pH}$ values at $96^{\circ} \mathrm{C}$ did not show a significant difference $(P<0.05)$, with an average of 5.86. Leroy et al. (2006) found a $\mathrm{pH}$ range from 5.27 to 6.13 for $C$. canephora by reviewing the literature. A pH value of 5.71 at $25^{\circ} \mathrm{C}$ was found for $C$. canephora (Bicho et al., 2013). In the sensorial analysis, the acidity of the coffee is an attribute of great importance. In terms of quality, the increase in acidity can be associated to inferior coffee quality. Coffee acidity may vary according to the stage of fruit maturation, place of origin, harvest and processing method, climatic conditions of the crop, harvest and drying (Clifford et al., 1987; Lima Filho et al., 2013). The C. canephora coffee samples in the present work were cultivated in the same place, had standard harvesting, processing and drying methods. These facts can explain the uniformity of the acidity of these coffees.

\section{Coffee sugars (C. canephora)}

The reducing (RS), non-reducing (N-RS) and total (TS) sugars found for $C$. canephora samples ranged from 0.66 to $0.39 \%$; 1.32 to $2.31 \%$; and 2.02 to $2.83 \%$, respectively. There was a statistical difference for these sugar contents among the samples, but the values found were similar. Non-reducing sugars, in particular, sucrose, are found in larger quantities in coffee, and are of great sensory importance. Pinheiro et al. (2012) found values of 2.04 to $2.82 \%$ of TS, 0.62 to $0.87 \%$ of RS and 1.40 to $2.49 \%$ of N-RS for samples of conilon coffee in Espírito Santo, Brazil.

Higher sugar contents in coffee give the beverage a sweeter taste. During the coffee roasting process, reducing sugars mainly react with amino acids (Maillard reaction), giving rise to desirable color compounds, responsible for the brown color of the coffee. Volatile compounds are produced in these reactions, which have a great effect on the aroma of the final product, resulting in better quality (Wang and Lim, 2017).

The sugars are precursors of the characteristic flavor and aroma of coffee, giving rise to substances belonging to the classes of furans, aldehydes and carboxylic acids that influence the quality of the final product (Farah et al., 2006).

\section{Bioactive constituents that influence the quality of $C$. canephora}

Chlorogenic acids (CA), trigonelline (Tr) and caffeine (Cf) are biologically active compounds present in coffees, which impact the quality of the beverage (Abrahão et al., 2008). The levels of chlorogenic acid (5-ACQ) found for $C$. canephora coffee samples presented a statistical difference. The values found ranged from 2.60 to $3.65 \%$. Lower levels of 
Table 1. Average of total titratable acidity (TTA), expressed as $\mathrm{mL}$ of $\mathrm{NaOH} 0.1 \mathrm{~mol} \mathrm{~L} / 100 \mathrm{~g}$ of dry coffee, $\mathrm{pH}$ at $25^{\circ} \mathrm{C}$ and $96^{\circ} \mathrm{C}$ for 21 samples of $C$. canephora cultivated at $720 \mathrm{~m}$ of altitude obtained from Incaper clones: Vitória (V1 to V13) and Robustão Capixaba (R1-R3, R6-R10).

\begin{tabular}{lccc}
\hline C. canephora(Clones) & TTA & $\mathrm{pH}(25 \circ \mathrm{C})$ & $\mathrm{pH}(96$ o $\mathrm{C})$ \\
\hline V1 & $201.67 \mathrm{a}$ & $5.92 \mathrm{~b}$ & $5.74 \mathrm{a}$ \\
V2 & $146.67 \mathrm{a}$ & $5.92 \mathrm{~b}$ & $5.82 \mathrm{a}$ \\
V3 & $146.67 \mathrm{a}$ & $5.99 \mathrm{~b}$ & $5.83 \mathrm{a}$ \\
V4 & $183.33 \mathrm{a}$ & $6.02 \mathrm{a}$ & $5.82 \mathrm{a}$ \\
V5 & $201.67 \mathrm{a}$ & $5.94 \mathrm{~b}$ & $5.86 \mathrm{a}$ \\
V6 & $143.67 \mathrm{a}$ & $5.93 \mathrm{~b}$ & $5.75 \mathrm{a}$ \\
V7 & $165.00 \mathrm{a}$ & $6.11 \mathrm{a}$ & $5.75 \mathrm{a}$ \\
V8 & $183.33 \mathrm{a}$ & $6.07 \mathrm{a}$ & $5.99 \mathrm{a}$ \\
V9 & $146.67 \mathrm{a}$ & $5.87 \mathrm{~b}$ & $6.00 \mathrm{a}$ \\
V10 & $128.33 \mathrm{a}$ & $5.91 \mathrm{~b}$ & $5.87 \mathrm{a}$ \\
V11 & $183.33 \mathrm{a}$ & $6.08 \mathrm{a}$ & $6.05 \mathrm{a}$ \\
V12 & $183.33 \mathrm{a}$ & $6.11 \mathrm{a}$ & $5.93 \mathrm{a}$ \\
V13 & $183.33 \mathrm{a}$ & $6.17 \mathrm{a}$ & $5.84 \mathrm{a}$ \\
R1 & $183.33 \mathrm{a}$ & $6.03 \mathrm{a}$ & $5.92 \mathrm{a}$ \\
R2 & $201.67 \mathrm{a}$ & $6.10 \mathrm{a}$ & $5.92 \mathrm{a}$ \\
R3 & $165.00 \mathrm{a}$ & $6.00 \mathrm{~b}$ & $5.90 \mathrm{a}$ \\
R6 & $201.67 \mathrm{a}$ & $6.00 \mathrm{~b}$ & $5.83 \mathrm{a}$ \\
R7 & $146.67 \mathrm{a}$ & $6.06 \mathrm{a}$ & $5.79 \mathrm{a}$ \\
R8 & $238.33 \mathrm{a}$ & $5.89 \mathrm{~b}$ & $5.76 \mathrm{a}$ \\
R9 & $183.33 \mathrm{a}$ & $5.83 \mathrm{~b}$ & $5.75 \mathrm{a}$ \\
R10 & $220.00 \mathrm{a}$ & $5.98 \mathrm{~b}$ & $5.73 \mathrm{a}$ \\
\hline Average & 178.09 & 5.99 & 5.86 \\
CV (\%) & 21.31 & 1.23 & 1.97 \\
Significance Test $\mathrm{F}$ (0.05) & ns & $*$ & $\mathrm{~ns}$ \\
\hline Means followed by the same letter belong to the same group according to the Scott-Knott test $(\mathrm{P}<5 \%)$. & \\
& & & \\
\hline
\end{tabular}

Table 2. Average of reducing sugars (RS), non-reducing sugars (N-RS) and total sugars (TS) for 21 samples of $C$. canephora cultivated at $720 \mathrm{~m}$ altitude obtained from Incaper clones: Vitória (V1 to V13) and Robustão Capixaba (R1-R3, R6-R10).

\begin{tabular}{lccc}
\hline $\begin{array}{l}\text { C. canephora } \\
\text { (Clones) }\end{array}$ & $\mathrm{RS}(\%)$ & $\begin{array}{c}\text { N-RS } \\
(\%)\end{array}$ & $\begin{array}{c}\text { TS } \\
(\%)\end{array}$ \\
\hline V1 & $0.66 \mathrm{a}$ & $2.00 \mathrm{a}$ & $2.66 \mathrm{a}$ \\
V2 & $0.52 \mathrm{~d}$ & $1.70 \mathrm{~b}$ & $2.21 \mathrm{~b}$ \\
V3 & $0.44 \mathrm{f}$ & $1.64 \mathrm{~b}$ & $2.09 \mathrm{~b}$ \\
V4 & $0.44 \mathrm{f}$ & $1.91 \mathrm{a}$ & $2.34 \mathrm{~b}$ \\
V5 & $0.47 \mathrm{f}$ & $1.54 \mathrm{~b}$ & $2.02 \mathrm{~b}$ \\
V6 & $0.73 \mathrm{~b}$ & $1.65 \mathrm{~b}$ & $2.38 \mathrm{~b}$ \\
V7 & $0.47 \mathrm{e}$ & $1.93 \mathrm{a}$ & $2.40 \mathrm{~b}$ \\
V8 & $0.55 \mathrm{~d}$ & $1.9 \mathrm{a}$ & $2.45 \mathrm{a}$ \\
V9 & $0.85 \mathrm{a}$ & $1.32 \mathrm{~b}$ & $2.15 \mathrm{~b}$ \\
V10 & $0.62 \mathrm{a}$ & $1.58 \mathrm{~b}$ & $2.21 \mathrm{~b}$ \\
V11 & $0.43 \mathrm{f}$ & $1.97 \mathrm{a}$ & $2.39 \mathrm{~b}$ \\
V12 & $0.52 \mathrm{~d}$ & $2.31 \mathrm{a}$ & $2.83 \mathrm{a}$ \\
V13 & $0.46 \mathrm{e}$ & $2.20 \mathrm{a}$ & $2.67 \mathrm{a}$ \\
R1 & $0.54 \mathrm{~d}$ & $1.96 \mathrm{a}$ & $2.50 \mathrm{a}$ \\
R2 & $0.68 \mathrm{c}$ & $1.59 \mathrm{~b}$ & $2.26 \mathrm{~b}$ \\
R3 & $0.46 \mathrm{e}$ & $1.69 \mathrm{~b}$ & $2.15 \mathrm{~b}$ \\
R6 & $0.65 \mathrm{c}$ & $1.99 \mathrm{a}$ & $2.64 \mathrm{a}$ \\
R7 & $0.43 \mathrm{f}$ & $1.9 \mathrm{a}$ & $2.33 \mathrm{~b}$ \\
R8 & $0.73 \mathrm{~b}$ & $1.89 \mathrm{a}$ & $2.61 \mathrm{a}$ \\
R9 & $0.57 \mathrm{~d}$ & $2.05 \mathrm{a}$ & $2.62 \mathrm{a}$ \\
R10 & $0.39 \mathrm{f}$ & $1.64 \mathrm{a}$ & $2.03 \mathrm{~b}$ \\
\hline Average & 0.55 & 1.83 & 2.38 \\
CV(\%) & 4.9 & 9.82 & 7.33 \\
Significance Test F (0.05) & $*$ & $*$ & $*$ \\
\hline
\end{tabular}


Table 3. Average of chlorogenic acid (CA: 5 -caffeoylquinic acid, 5-CQA), trigonelline ( $\mathrm{Tr}$ ) and caffeine (Cf) expressed as $\mathrm{g} 100 \mathrm{~g}^{-1}$ of coffee on a dry basis for 21 samples of $C$. canephora cultivated at $720 \mathrm{~m}$ altitude obtained from Incaper clones: Vitória (V1 to V13) and Robustão Capixaba (R1-R3, R6-R10).

\begin{tabular}{llll}
\hline $\begin{array}{l}\text { C. canephora } \\
\text { (Clones) }\end{array}$ & CA & Tr & Cf \\
V1 & $3.13 \mathrm{~b}$ & $1 \%)$ & $(\%)$ \\
V2 & $2.94 \mathrm{~b}$ & $0.94 \mathrm{a}$ & $2.46 \mathrm{~b}$ \\
V3 & $3.46 \mathrm{a}$ & $0.96 \mathrm{a}$ & $2.228 \mathrm{c}$ \\
V4 & $3.02 \mathrm{~b}$ & $0.95 \mathrm{a}$ & $2.60 \mathrm{~b}$ \\
V5 & $2.60 \mathrm{c}$ & $0.90 \mathrm{a}$ & $2.49 \mathrm{~b}$ \\
V6 & $3.58 \mathrm{a}$ & $0.96 \mathrm{a}$ & $2.06 \mathrm{c}$ \\
V7 & $3.43 \mathrm{a}$ & $0.85 \mathrm{a}$ & $2.89 \mathrm{a}$ \\
V8 & $3.65 \mathrm{a}$ & $0.88 \mathrm{a}$ & $2.49 \mathrm{~b}$ \\
V9 & $3.44 \mathrm{a}$ & $0.91 \mathrm{a}$ & $2.75 \mathrm{a}$ \\
V10 & $3.38 \mathrm{a}$ & $0.91 \mathrm{a}$ & $2.48 \mathrm{~b}$ \\
V11 & $3.20 \mathrm{a}$ & $1.01 \mathrm{a}$ & $2.51 \mathrm{~b}$ \\
V12 & $3.37 \mathrm{a}$ & $0.96 \mathrm{a}$ & $2.43 \mathrm{~b}$ \\
V13 & $3.05 \mathrm{~b}$ & $0.94 \mathrm{a}$ & $2.59 \mathrm{~b}$ \\
R1 & $3.33 \mathrm{a}$ & $0.95 \mathrm{a}$ & $2.32 \mathrm{c}$ \\
R2 & $3.51 \mathrm{a}$ & $0.87 \mathrm{a}$ & $2.51 \mathrm{~b}$ \\
R3 & $3.08 \mathrm{~b}$ & $0.89 \mathrm{a}$ & $2.51 \mathrm{~b}$ \\
R6 & $2.65 \mathrm{c}$ & $0.89 \mathrm{a}$ & $2.45 \mathrm{~b}$ \\
R7 & $3.06 \mathrm{~b}$ & $0.84 \mathrm{a}$ & $2.21 \mathrm{c}$ \\
R8 & $3.19 \mathrm{a}$ & $0.96 \mathrm{a}$ & $2.35 \mathrm{c}$ \\
R9 & $2.83 \mathrm{c}$ & $1.02 \mathrm{a}$ & $2.31 \mathrm{c}$ \\
R10 & $3.42 \mathrm{a}$ & $0.85 \mathrm{a}$ & $2.41 \mathrm{c}$ \\
\hline Average & 3.21 & 0.93 & $2.35 \mathrm{c}$ \\
CV (\%) & 7.62 & 8.55 & 2.45 \\
Significance Test F (0.05) & $*$ & ns & 5.76 \\
\hline Means followed by the same letter belong to the same group according to the Scott-Knott test (P <0.05). & \\
\hline
\end{tabular}

chlorogenic acids are desirable for better coffee quality, as these substances are degraded during the roasting phase, producing the compounds caffeic acid, lactones and different phenols, through Maillard and Strecker reactions, resulting in increased bitterness and astringency (Shan et al., 2017). There was no significant difference in the values of trigonelline found for the 21 samples of $C$. canephora coffee. The total average value found was $0.93 \%$, which is in accordance with the literature. In raw coffee beans the trigonelline content is around $1 \%$. Trigonelline is responsible for the formation of degradation products in the roasting process. Among these products, pyrroles and pyridines stand out, since they are highly important for coffee aroma (Monteiro and Trugo, 2005; Vignoli et al., 2014). In addition to these compounds, trigonelline is a precursor of niacin, a vitamin which has nutritional importance (Farah et al., 2006). The average caffeine content found in C. canephora coffee samples was around $2.20 \%$, almost double the value found for $C$. arabica, which presents on average $1.40 \%$ of this substance (Leroy et al., 2006). In the present work, the caffeine contents presented significant differences among the samples of $C$. canephora, with values ranging from 2.06 to $2.89 \%$. Ky et al. (2001) found an average value of $2.54 \%$ caffeine in conilon coffee from different African countries.

Caffeine is an alkaloid present in teas, soft drinks and coffee, which acts on the human body in the central nervous system, having a stimulant and diuretic effect. During the roasting process, caffeine is very stable, and although it is an odorless substance, it is bitter and can contribute to this sensorial characteristic of coffee (Monteiro and Trugo, 2005).

\section{Sensory analysis of $C$. canephora}

The 21 samples of $C$. canephora were submitted to sensory analysis and there was no statistical difference in the scores obtained for any of the attributes tested. The final mean value was 77.44 points (Table S3, Supplementary). By the UCDA protocol (2010), this score ranks in the 'good quality' range. This result suggests that at $720 \mathrm{~m}$ altitude the $C$. canephora of the clonal cultivars 'Vitoria' (V1-V13) and 'Robustão Capixaba' (R1-R3, R6-R10) were obtained with similar flavors and aroma and had good drink acceptance (superior/premium). Sturm et al. (2010), investigating the relationship between altitude and quality of $C$. canephora, used crops with different genotypes of this species in order to avoid interactions of genotypes with specific environments. The crops were located in the cities of Alegre and Mimoso do Sul in the state of Espírito Santo, Brazil. The coffees from seven rural properties were planted at different altitudes: below $250 \mathrm{~m}$, from 250 to $500 \mathrm{~m}$ and above $500 \mathrm{~m}$, and were submitted to sensory analysis. Based on the results and statistical analysis, there was an influence of the altitude on the quality of the conilon coffee drink; the higher the altitude, the higher the beverage quality.

\section{Materials and methods}

\section{Genetic materials and grain sample preparation}

Twenty-two genetic materials of Coffea canephora from the Incaper breeding program were analyzed, grown at the Experimental Farm of Venda Nova (FEVN), at 720 meters 
above sea level. The genetic materials were the clones of the cultivars 'Vitória Incaper 8142' (V1 to V13) and 'Emcaper 8141 Robustão Capixaba' (R1-R3, R6-R10).

Grain samples, obtained in the 2016 harvest, were prepared at Incaper, from an experiment conducted at the Experimental Farm of Venda Nova do Imigrante (FEVN) in a randomized block design with 21 treatments, 4 replications, 8 plants per plot with spacing of $3.0 \times 1.0 \mathrm{~m}$.

During the harvest, in July-August 2016, $3.0 \mathrm{~kg}$ of cherry coffee were harvested from each plot for post-harvest evaluations regarding sensory and physicochemical analysis. The samples of cherry coffee were dried on covered ground until reaching $11-12 \%$ humidity (natural processing). They were then stored in closed bags and processed in February 2017. The four replicates were grouped and 200 grams of the 21 treatments were transported to the Analytical Central and Chemistry Laboratory of the Exact, Natural and Health Sciences Center (CCENS) of the Federal University of Espírito Santo (UFES), in Alegre-ES, for the physicochemical analysis.

\section{Total Titratable Acidity (TTA)}

Total titratable acidity (TTA) was determined by titration with $0.1 \mathrm{~mol} \mathrm{~L}^{-1} \mathrm{NaOH}$ (expressed as $\mathrm{mL}$ of $\mathrm{NaOH} 0.1 \mathrm{~mol} \mathrm{~L}^{-}$ $1 / 100 \mathrm{~g}$ dry coffee) according to procedures described in AOAC (1990).

\section{pH at $25^{\circ} \mathrm{C}$ and after heating at $96^{\circ} \mathrm{C}$}

The $\mathrm{pH}$ measurements were made at $25^{\circ} \mathrm{C}$ and after heating at $96^{\circ} \mathrm{C}$ and were performed on a Digimed DM-22pHmeter according to procedures described by IAL (1985).

\section{Analysis of sugars}

Total and reducing sugars were extracted by the Lane-Enyon method, cited by AOAC (1990) and determined using the Somogy technique, adapted by Nelson (1944). Non-reducing sugars were obtained by calculating the difference between total and reducing sugars. Values were expressed as percentages.

\section{Chlorogenic acid, trigonelline and caffeine}

For the simultaneous determination of chlorogenic acid, trigonelline and caffeine, $0.5 \mathrm{~g}$ of ground coffee was dissolved in $100 \mathrm{~mL}$ of Mili-Q water at $80^{\circ} \mathrm{C}$ under magnetic stirring for 15 minutes. After this time, simple filtration was carried out and the filtrate was collected in a $100 \mathrm{~mL}$ volumetric flask. After the filtrate cooled to room temperature, it was filtered through a syringe membrane filter $(0.45 \mu \mathrm{m}$ pore size) and the aqueous coffee extracts were placed in 1-mL vials. These extracts were analyzed by high-performance liquid chromatography (HPLC) using a Shimadzu chromatograph (Prominence model) with a Shimadzu Shim-pack VP-ODS reverse phase C-18 column ( $250 \mathrm{~mm}$ long $\times 4.6 \mathrm{~mm}$ ID). The system was coupled to a Shimadzu UV-Visible spectrophotometric detector (SPD-20A model), with a CBM-20A system controller.The analysis conditions used were: mobile phase composed of HPLC grade methanol, Mili-Q water and HPLC grade acetic acid in the ratio of 20:80:1; flow of $1 \mathrm{~mL} \mathrm{~min}^{-1}$; column temperature was kept at $40^{\circ} \mathrm{C}$ and wavelength detector was set at $272 \mathrm{~nm}$ (Abrahão et al., 2008).

The external standard method was used in the simultaneous quantification of chlorogenic acid, trigonelline and caffeine contents in $C$. canephora coffee samples. For this, standard substance (Sigma-Aldrich) solutions of known concentrations were prepared and analyzed under the conditions mentioned above. The calibration curves were obtained with $R^{2}>0.99$ from the peak areas obtained in the chromatograms for each standard substance at different concentrations. The equations obtained were used to calculate the amount of the target compounds present in the coffee extracts.

The chlorogenic acid solutions (5-caffeoylquinic acid) used to establish the calibration curve were prepared at concentrations of $25,50,100,150$ and $300 \mu \mathrm{g} \mathrm{m}^{-1}$ (ppm); trigonelline solutions (3-carboxy-1-methylpyridinium chloride) were prepared at $12.5,25,50,100$ and $150 \mu \mathrm{g} \mathrm{mL}$ ${ }^{1} ;$ and caffeine (1,2,7-trimethylxanthine) solutions were prepared at concentrations of $40,60,80,100$ and $200 \mu \mathrm{g} \mathrm{mL}$

\section{Sensorial analyses}

Sensorial analyses were performed according to the methodology proposed by the Uganda Coffee Development Authority (UCDA, 2010). The samples of C. canephora coffees of the cultivars 'Vitória Incaper 8142' (V1 to V13) and 'Emcaper 8141 Robustão Capixaba' (R1-R3, R6-R10) were left standing for 45 days and subsequently classified by type and by sieving. For the roasting process, coffees with $100 \%$ sieve 15 and above were admitted. The roaster used was Laboratto TGP-2 with the Agtron-SCA disc set. The roasting point of these samples was between the colors determined by the discs no 65 and no 55 for specialty coffees (SCAA, 2013). Roasting was executed 24 hours in advance and grinding respected the time of 8 hours of rest after roasting. The roasting was carried out for 9 to 10 minutes and, after roasting and cooling, the samples remained sealed.

The Bunn G3 electric crusher was used to grind the coffees to obtaina medium to coarse particle sizes. Five cups of each coffee batch were used and the ideal proportion of $8.25 \mathrm{~g}$ of ground coffee per $150 \mathrm{~mL}$ of water (SCAA, 2013) was adopted. After the water reached $92-95^{\circ} \mathrm{C}$, infusion was performed. When the cup temperature reached $55^{\circ} \mathrm{C}$ the QGraders started the evaluation after 4 minutes of infusion. The sensory analysis of the coffees was carried out by a panel of six (6) tasters, all of them Q Certified Robusta Graders (skilled and credible Robusta coffee cuppers, certified by the Coffee Quality Institute, CQI). This minimum number of evaluators in the sensorial analysis was initially proposed by Pereira et al. (2016), in order to reduce the subjectivity of the sensory analysis of coffees.

\section{Statistical analysis}

Data was submitted to analysis of variance for each response variable and, in significant cases $(P<5 \%)$, the ScottKnott averages group test $(\mathrm{P}<5 \%)$ was applied. Analyses were performed using the GENES software (Cruz, 2016). 


\section{Conclusion}

Based on the results, it can be inferred that the cultivation of C. canephora at an altitude of $720 \mathrm{~m}$ can result in higher quality coffees, as the chemical composition of the conilon and robust genotypes present similarities and are compatible with data obtained for higher-value coffee aggregates. The 21 samples of $C$. canephora coffee grown at $720 \mathrm{~m}$ of altitude had similar mean values of total titratable acidity (TTA), $\mathrm{pH}$ at $96^{\circ} \mathrm{C}$ and trigonelline contents, which did not present significant differences $(P<5 \%)$. The values of reducing, non-reducing and total sugars were different for the genotypes. The levels of chlorogenic acid (5-CQA) found for all $C$. canephora coffee samples were lower than those reported in the literature. The percentages of caffeine found were close to the average value for this species.

From a sensory standpoint, the coffees were similar. There was no statistical difference in the final score for the 21 analyzed samples and the average of 77.44 points indicates good drinking quality for these coffees. Thus, the cultivation of $C$. canephora coffee at an altitude of $720 \mathrm{~m}$ can be viable for obtaining superior coffee.

\section{Acknowledgments}

The authors are grateful for the financial support and the productivity grant to PF Pinheiro granted by the Foundation for Support to Research and Innovation of Espírito Santo (FAPES) and the National Council of Scientific and Technological Development (CNPq). "This study was financed in part by the Coordenação de Aperfeiçoamento de Pessoal de Nível Superior - Brasil (CAPES) - Finance Code 001".

\section{References}

Abrahão SA, Pereira RGFA, Lima AR, Ferreira EB, Malta MR (2008) Compostos bioativos em café integral e descafeinado e qualidade sensorial da bebida. PesqAgr Bras. 43:1799-1804.

AOAC, Association of Official Analytical Chemists (1990) Official methods of analysis of the Association of Official Analytical Chemists.15. ed. Washington.

Bicho NC, Leitão AE, Ramalho JC, De Alvarenga NB, Lidon FC (2013) Identification of Chemical Clusters Discriminators of Arabica and Robusta Green Coffee. Int J Food Prop. 16:895-904.

Borém FM, Coradi PC, Saath R, Oliveira JA (2008) Qualidade do café natural e despolpado após secagemem terreiro e com altas temperaturas. Cien Agr. 32:1609-1615.

Bragança SM, Carvalho CHS, Fonseca AFA, Ferrão RG (2001) Variedades clonais de café Conilon para o Estado do Espírito Santo. Pesq Agropec Bras. 36:765-770.

Clifford MN (1987) Chemical and physical aspects of green coffee products. In Clifford, M.N.; Wilson, K.C.; Eds. Coffee, Botany, Biochemistry and Production of Beans and Beverage; Croom Helm \& Methuen Inc., New York.

Conab (2017) Companhia Nacional de Abastecimento. Acompanhamento da safra brasileira: Café. Quarto Levantamento, v.4, n.4, Dezembro de 2017, Brasília.

Coradi PC, Borém FM, Oliveira JA (2008) Qualidade do café natural e despolpado após diferentes tipos de secagem e armazenamento. Rev Bras Eng Agr Amb. 12:181-188.
Cruz CD (2016) Genes Software-extended and integrated with the R, Matlab and Selegen. Acta Sci Agron. 38:547552.

Dadalto GG, Barbosa C A (1997) Zoneamento agroecológico para a cultura do café no Estado do Espírito Santo. SEAGES.

Dandengo MCJ, Sousa EF, Reis EF, Amaral Gravina G (2014) Crescimento e qualidade de mudas de café conilon produzidas em diferentes recipientes e níveis de sombreamento. Coffee Sci. 8:500-509.

Fagan EB, De Souza CHE, Pereira NMB, Machado VJ (2011) Efeito do tempo de formação do grão de café (Coffea sp) na qualidade da bebida. Biosc J. 27:729-738.

Farah A, de Paulis T, Moreira DP, Trugo LC, Martin PR (2006) Chlorogenic Acids and Lactones in Regular and WaterDecaffeinated Arabica Coffees. J Agric Food Chem. 25:374381.

Fernandes SM, Pereira RGFA, Pinto NAVD, Nery MC, Pádua FRM (2003) Constituintes químicos e teor de extrato aquoso de cafés arábica (Coffea arabica L.) e conilon (Coffea canephora Pierre) torrados. Cien Agr. 27:10761081.

Ferrão RG (Org.); Fonseca AFA (Org.), FerrãoMAG (Org.), Demuner LH (Org.) (2017) Café Conilon. 2. ed. Vitória: DCM/Incaper, Vitória.

Ferrão RG, Ferrão MAG, Fonseca A FA, Silveira J S M, Bragança SM, Ferrão, L.M.V.(1999) Emcapa 8141 Robustão Capixaba: variedade clonal de café conilon para a região sudene no estado do Espírito Santo. Rev Facul de Linhares.1: 77-82.

Ferrão RG, Silva AES, Ferrão MAG, Fonseca AFA (2013) Cafeicultura responde por $43 \%$ da produção agrícola no Espírito Santo. Vis Agric (USP/ESALQ).12:95-96.

Ferrão RG, Fonseca AFA, Ferrão MAG, Bragança SM, Ferrão LMV (2000) EMCAPA 8151 - robusta tropical: variedade melhorada de café conilon de propagação por sementes para o Estado do Espírito Santo. Simp de Pesq dos Cafés do Brasil. 1: 413-416.

Figueiredo LP, Borém FM, Ribeiro FC, Giomo GS, Malta MR, Taveira JHS (2018) Sensory Analysis and Chemical Composition of 'Bourbon' Coffees Cultivated in Different Environments. Coffee Sci. 13:122-131.

Fritzsons E, Mantovani LE, Aguiar AV (2008) Relação entre altitude e temperatura: uma contribuição ao zoneamento climático no Estado do Paraná. Rev de Est Amb.10:49-64.

IAL, Instituto Adoflo Lutz (1985) Normas Analíticas do Instituto Adolfo Lutz.v 1: Métodos Químicos e Físicos para Análise de Alimentos. IMESP, 3. ed., São Paulo

Laviola BG, Martinez HEP, Salomão LCC, Cruz CD, Medonça SM, Neto AP (2007) Alocação de fotoassimilados em folhas e frutos de cafeeiro cultivado em duas altitudes. Pesq Agr Bras. 1:1521-1530.

Leroy T, Ribeyre F, Bertrand B, Charmetant P, Dufour M, Montagnon C, Marraccini P, Pot D (2006) Genetics of coffee quality. Braz J Plant Physiol. 18:229-242.

Lima Filho T, Della Lucia SM, Saraiva SH, Sartori MA (2013) Composição físico-química e qualidade sensorial de café conilon produzido no Estado do Espírito Santo e submetido a diferentes formas de processamento. Semina: Cienc Agr. 34:1723-1730. 
Martins E, Aparecido E O, Santos LS, Mendonça JMA, Souza PS (2015) Weather influence in yield and quality coffee produced in South Minas Gerais region. Coffee Sci.10:499506.

Matiello JB (1991) Clima e solos para o cafeeiro. In: O café : do cultivo ao consumo. Globo, São Paulo.

Monteiro MC, Trugo LC (2005) Determinação de compostos bioativos em amostras comerciais de café torrado. Quim Nova. 28: 637-641.

Nelson N (1944) A photometric adaptation of Somogy method for determination of glucose. J Biol Chem. 53:375384.

Partelli FL, Partelli O, Partelli AS, Borém FM, Da Silva JH (2014) Quality of conilon coffee dried on a concrete terrace in a greenhouse with early hulling. Semina: Ciênc Agrár. 35:2367-2372.

Pereira, L. L., Guarçoni, RC, Pulini, IC, Cardoso, WC, Caten, CSt (2016) Tamanho Ótimo do Número de Provadores de Café com Uso do Protocolo SCA Great Size Number of Coffee Tasters With the Use of SCA Protocol. 19:20-21.

Pinheiro PF, Costa AV, Queiroz VT, Alvarenga LM, Partelli FL (2012) Qualidade do café conilon sob diferentes formas de secagem. Enc Bio.8:1481-1489, 2012.

Ramalho AR, Rocha RR, Souza FF, Veneziano W, Teixeira AL (2016) Progresso genético da produtividade de café beneficiado com a selęão de clones de cafeeiro "Conilon". Rev Cien Agr.47:516-523.
SCAA, Specialty Coffee Association of American (2013) Protocols. January, http://www.scaa.org/PDF/resources/cuppingprotocols.pdf. (Accessed 2-10- 2017).

Schmidt CAP, Miglioranza E, Prudêncio SH (2008) Interação da torra e moagem do café napreferência do consumidor do oesteparanaense. Cien Rural. 38:1111-1117.

Shan J, Wang X, Han S, Kondo N (2017) Application of Curve Fitting and Wavelength Selection Methods for Determination of Chlorogenic Acid Concentration in Coffee Aqueous Solution by Vis/NIR Spectroscopy. Food Anal Method. 10:999-1006.

Sturm GM, Coser SM, Senra JFB, Ferreira MFS, Ferreira A. (2010) Qualidade Sensorial de Café Conilon em Diferentes Altitudes. Enc Bio. 6:1-7.

Uganda Coffee Development Authority.UCDA.Annual Report (2011/2012). https://ugandacoffee.go.ug/annual-reports. (Accessed 2-08- 2017).

Vignoli JA, Viegas MC, Bassoli DG, Benassi MT (2014) Roasting process affects differently the bioactive compounds and the antioxidant activity of arabica and robusta coffees. Food Res Int. 61:279-285.

Wang X, Lim L-T (2017) Investigation of $\mathrm{CO}_{2}$ precursors in roasted coffee. Food Chem. 219:185-192. 